\title{
ANALISIS HASIL KERJA PADA UJI KOMPETENSI PRAKTIK KEJURUAN TEKNIK PEMESINAN SISWA SMK
}

\author{
Pradika Noviandani $^{1}$, Purnawan $^{2}$, Wardaya $^{3}$ \\ Departemen Pendidikan Teknik Mesin \\ Universitas Pendidikan Indonesia \\ Jl. Dr. Setiabudhi No. 207 Bandung 40154 \\ pradika.noviandani@yahoo.com
}

\begin{abstract}
ABSTRAK
Tujuan penelitian ini, adalah untuk mengetahui gambaran hasil kerja pada pelaksanaan uji kompetensi praktik kejuruan teknik pemesinan di SMK Negeri 6 Bandung. Metode yang digunakan adalah metode deskritif. Data dijaring melalui studi observasi secara langung pada pelaksanaan uji kompetensi praktik kejuruan teknik pemesinan untuk pekerjaan membubut. Jenis proses terdiri atas membubut diameter, membubut panjang, mengebor diameter, membubut alur, membubut ulir, membubut tirus dan mengebor kedalaman. Hasil kerja uji kompetensi praktek diukur menggunakan jangka sorong analog dengan ketelitian $0.05 \mathrm{~mm}$ untuk mengetahui dimensi produk hasil kerja. Subjek penelitian sebanyak 30 siswa. Rata-rata nilai produk hasil kerja dalam proses pembubutan adalah 16. Distribusi penilaian untuk aspek hasil kerja berdasarkan kriteria yang dibuat adalah $13.33 \%, 40 \%, 40 \%, 6,67 \%$ untuk masing-masing kategori A,B,C dan E.
\end{abstract}

Kata Kunci: kinerja, pemesinan bubut, kompetensi

\section{PENDAHULUAN}

Sekolah menengah kejuruan (SMK) merupakan pendidikan pada jenjang menengah yang mengutamakan pengembangan keterampilan siswa, selain itu juga SMK mencetak lulusannya yang kompeten di bidangnya dapat bekerja di dunia industri namun kenyataannya angka pengangguran pada lulusan SMK pada tahun 2013 sebesar 11,81\% atau 847.052 orang dari total 7.170 .523 orang berdasarkan Badan Pusat Stastistik (BPS), Angka ini menunjukkan bahwa masih belum tercapainya tujuan SMK dalam mempersiapkan peserta didik agar menjadi manusia produktif, mampu bekerja mandiri, mengisi lowongan pekerjaan yang ada di dunia usaha / dunia Industri sebagai tenaga kerja tingkat menengah (Widayanti, 2008).

Pelaksanaan uji kompetensi merupakan salah satu standar kelulusan siswa di SMK. Penilaian uji kompetensi di SMK diatur kedalam Peraturan Menteri Pendidikan Nasional Nomor 78 Tahun 2008 tentang ujian nasional dan keputusan BSNP Nomor 1513/BNSP/XI/2008 tentang Prosedur Operasi Standar (POS) Ujian Nasional bahwa: mengingat struktur kurikulum SMK mencakup kognitif dan psikomotorik yang meliputi pula

\footnotetext{
${ }^{1}$ Mahasiswa Departemen Pendidikan Teknik Mesin FPTK UPI

${ }^{2}$ Dosen Departemen Pendidikan Teknik Mesin FPTK UPI

${ }^{3}$ Dosen Departemen Pendidikan Teknik Mesin FPTK UPI
} 
aspek afektik. Maka Ujian Nasional Kompetensi Keahlian Kejuruan dirancang dalam bentuk teori dan praktek kejuruan (Individual Task).

Tujuan dari penilaian kompetensi adalah untuk menetapkan keberhasilan peserta didik dalam menguasai satu unit kompetensi dengan mengacu kepada standar kompetensi nasional. Badan Standar Nasional Pendidikan (BSNP) telah menentukan standar penilaian dalam pelaksanaan uji kompetensi dalam lembar penilaian ujian pratik kejuruan. Ada beberapa kriteria tertentu dalam penilaian yang merujuk kepada kompetensi yang diharapkan (BSNO, 2013). Aspek tersebut meliputi lima aspek yang menjadi standar acuan penilaian proses uji kompetensi praktek kejuruan diantaranya aspek persiapan kerja, aspek proses (sistematika dan cara kerja), aspek hasil kerja, aspek sikap kerja dan aspek waktu. Diantara aspek penilaian tersebut, menggunakan lebar penilaian dari BNSP.

Apabila melihat dari tabel diatas jelas format penilaian hasil kerja oleh BSNP pada uji kompetensi belum sesuai dan apabila dilihat dari format penilaian dari dunia industri, hanya mengacu pada sistem go dan no go. Hal inilah yang menyebabkan perbedaan format penilaian, aspek penilaian hasil kerja pada pelaksanaan uji kompetensi praktik kejuruan memiliki bobot sebesar $40 \%$, bobot ini sangat besar dibandingkan dengan aspek yang lainnya. Format penilaian hasil kerja ini meliputi pada hasil dimensi membubut, sehingga lulusan dari uji kompetensi ini menghasilkan siswa yang kompeten bukan sekedar formalitas dalam uji kompetensi praktik kejuruan. Sehingga salah satu aspek yaitu aspek hasil kerja pada pelaksanan uji kompetensi praktik kejuruan patut ditelurusi lebih lanjut tentang format penilaian aspek hasil kerja (Jihad dan Haris, 2013).

\section{METODE PENELITIAN}

Penelitian ini menggunakan metode deskiptif analisis. Hal ini digunakanuntuk menguraikan dan menjelaskan permasalahan yang ada, dengan jalan mengumpulkan data yang diperoleh di lapangan, menganalisis data untuk menjawab masalah, merumuskan kesimpulan dan menuliskan laporan. Populasi dalam penelitian ini adalah seluruh siswa tingkat XII Teknik Pemesinan di SMK Negeri 6 Bandung tahun pelajaran 2013/2014, dalam satu angkatan dengan jumlah 120 siswa yang terdiri atas empat kelas, jumlah siswa setiap kelasnya berkisar 29-31 siswa. 


\section{HASIL PENELITIAN}

Berdasarkan sampel yang diambil yaitu 30 siswa dalam satu kelas, dalam penelitian ini dapat dilihat hasil kerja siswa pada proses membubut. Analisis data menggunakan format penilaian yang telah dibuat (Tabel 1).

Tabel 1. Format penilaian hasil kerja pemesinan

\begin{tabular}{|c|c|c|c|}
\hline NO & UKURAN YANG DIMINTA & TOLERANSI & KRITERIA \\
\hline 1 & Membubut $\varnothing 14$ & $\pm 0,2$ & $\begin{array}{l}\mathrm{A}=8,43-8,57 \\
\mathrm{~B}=8,36-8,43 \text { dan } 8,57-8,64 \\
\mathrm{C}=8,30-8,36 \text { dan } 8,64-8,70 \\
\mathrm{E}=<8,30 \text { dan }>8,70 \\
\mathrm{~A}=13,93-14,07 \\
\mathrm{~B}=13,86-13,93 \text { dan } 14,07-14,14 \\
\mathrm{C}=13,80-13,86 \text { dan } 14,14-14,20 \\
\mathrm{E}=\langle 13,80 \text { dan }>14,20\end{array}$ \\
\hline 4 & Membubut $\varnothing 19$ & $\pm 0,2$ & $\begin{array}{l}\mathrm{A}=18,93-19,07 \\
\mathrm{~B}=18,86-18,93 \text { dan } 19,07-19,14 \\
\mathrm{C}=18,80-18,86 \text { dan } 19,14-19,20 \\
\mathrm{E}=<18,80 \text { dan }>19,20 \\
\mathrm{~A}=11,93-12,07 \\
\mathrm{~B}=11,86-11,93 \text { dan } 12,07-12,14 \\
\mathrm{C}=11,80-11,86 \text { dan } 12,14-12,20 \\
\mathrm{E}=<11,80 \text { dan }>12,20\end{array}$ \\
\hline 5 & Membubut panjang ulir 20 & $\pm 0,2$ & $\begin{array}{l}A=19,93-20,07 \\
B=19,86-19,93 \text { dan } 20,07-20,14 \\
C=19,80-19,86 \text { dan } 20,14-20,20 \\
E=<19,80 \text { dan }>20,20\end{array}$ \\
\hline 6 & Membubut jarak alur 2,5 & $\pm 0,1$ & $\begin{array}{l}A=2,46-2,54 \\
B=2,42-2,46 \text { dan } 2,54-2,58 \\
C=2,40-2,42 \text { dan } 2,58-2,60 \\
E=<2,40 \text { dan }>2,60\end{array}$ \\
\hline 7 & Membubut panjang tirus 50 & $\pm 0,3$ & $\begin{array}{l}A=49,90-50,10 \\
B=49,80-49,90 \text { dan } 50,10-50,20 \\
C=49,70-49,80 \text { dan } 50,20-50,30 \\
E=<49,70 \text { dan }>50,30\end{array}$ \\
\hline 8 & Membubut panjang 100 & $\pm 0,3$ & $\begin{array}{l}A=99,90-100,10 \\
B=99,80-99,90 \text { dan } 100,10-100,20 \\
C=99,70-99,80 \text { dan } 100,20-100,30 \\
E=<99,70 \text { dan }>100,30\end{array}$ \\
\hline 9 & Membubut panjang benda 170 & $\pm 0,5$ & $\begin{array}{l}\mathrm{A}=169,83-170,17 \\
\mathrm{~B}=169,66-169,83 \text { dan } 170,17-170,34 \\
\mathrm{C}=169,50-169,66 \text { dan } 170,34-170,50 \\
\mathrm{E}=\langle 169,50 \text { dan }>170,50\end{array}$ \\
\hline 10 & Mengebor kedalaman 37 & $\pm 0,3$ & $\begin{array}{l}A=36,90-37,10 \\
B=36,80-36,90 \text { dan } 37,10-37,20 \\
C=36,70-36,80 \text { dan } 37,20-37,30 \\
E=<36,70 \text { dan }>37,30\end{array}$ \\
\hline 11 & Mengebor kedalaman 50 & $\pm 0,3$ & $\begin{array}{l}A=49,90-50,10 \\
B=49,80-49,90 \text { dan } 50,10-50,20 \\
C=49,70-49,80 \text { dan } 50,20-50,30 \\
E=<49,70 \text { dan }>50,30\end{array}$ \\
\hline
\end{tabular}




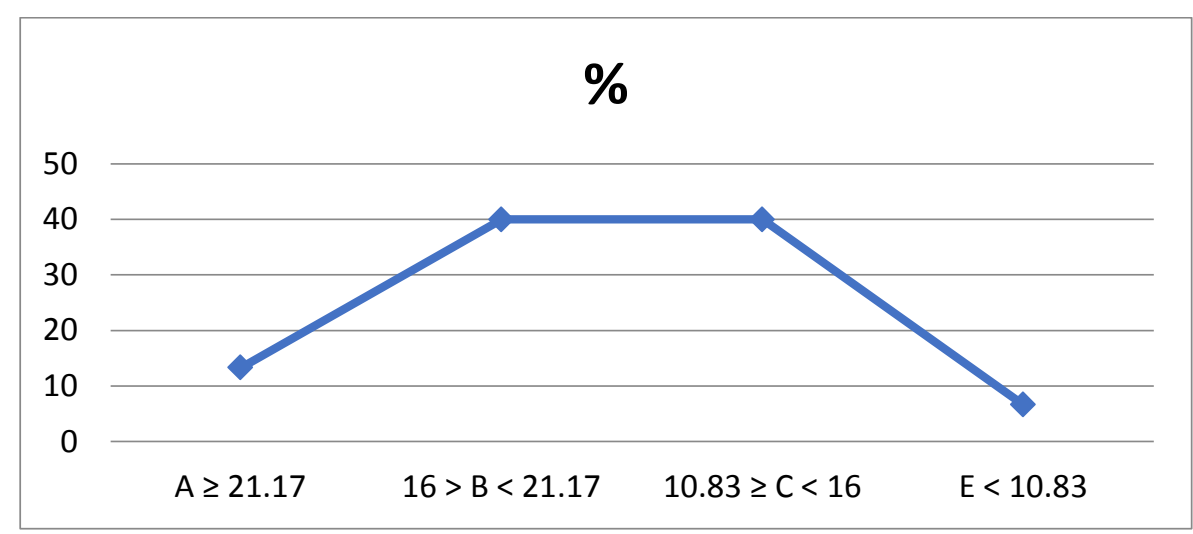

Gambar 1. Grafik penilaian hasil kerja keseluruhan

Hasil tersebut menunjukkan (Gambar 1) bahwa siswa yang mendapatkan kategori A sebesar $13,33 \%$,siswa yang mendapatkan kategori B sebesar $40 \%$, siswa yang mendapatkan kategori C sebesar $40 \%$, dan siswa yang termasuk kedalam kategori E sebesar 6,67 \%. Angka presentasi ini berdasarkan kualitas geometri produk hasil kerja secara keseluruhan. Bila dicermati dari grafik 1 standar deviasi > $5 \%$,sehingga semakin besar nilai standar deviasi maka menandakan bahwa data memiliki kecenderungan yang berbeda satu sama lain atau memiliki variasi yang tinggi. Namun melebar ini menandakan bahwa grafik menghasilkan produk yang tidak presisi yang di sebabkan oleh mesin. Mesin produksi presisi (tepat, atau keterulangan tinggi) biasanya akan mempunyai karateristik variabilitas (keadaan bervariasi kecenderungan berubah-rubah) proses yang kecil namun sebaliknya mesin produksi yang tidak presisi (serta tidak otomatik) cenderung untuk menghasilkan produk dengan variabilitas yang besar (Rochim, 2001).

Presentasi siswa yang termasuk dalam kategori E, ini merupakan sebuah kegagalan dalam pelaksanaan pembelajaran berbasis kompetensi, pembelajaran kompetensi merupakan tujuan dari proses pembelajaran dan pelatihan, sehingga setelah melalukan pembelajaran dan pelatihan siswa memperoleh pengetahuan baru, keterampilan baru dan sikap baru, melalui pembelajaran kompetensi ini mutu lulusan peserta didik lebih bermakna dalam kehidupannya, dalam arti lulusan peserta didik dapat bersaing didunia industri.

Kategori data hasil kerja setiap tipe proses pada pelaksanaan uji kompetensi praktik kejuruan (Gambar 2) berdasarkan penilaian dengan mengacu pada penilaian didunia industri tanpa menghilangkan pembobotan nilai dari BSNP. 


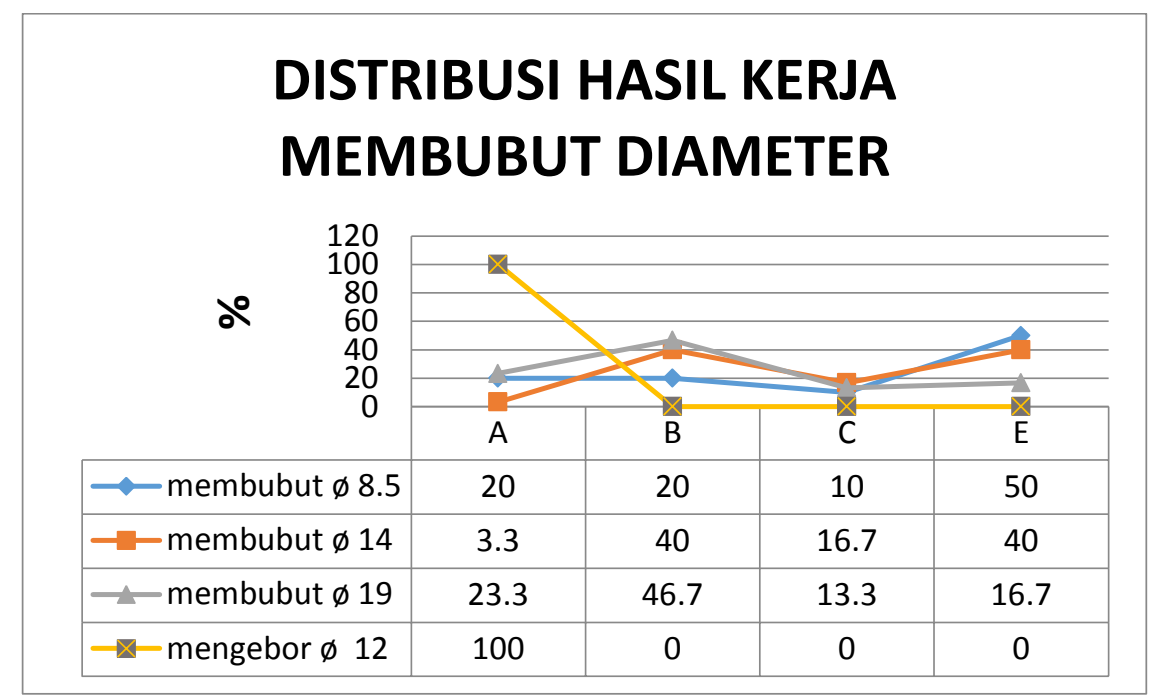

Gambar 2. Grafik penilaian hasil kerja pada membubut dan mengebor

Apabila dicermati dengan baik, (Gambar 2) terlihat bahwa hasil penilaian pada proses membubut diameter memiliki titik-titik (koordinat) cenderung berimpitan, artinya, nilai- nilai yang diperoleh tidak memiliki perbedaan yang signifikan, hal ini diperkuat dengan nilai standar deviasi menunjukkan bahwa data semakin homogen, atau memiliki nilai identik kecuali pada proses mengebor $\varnothing 12$, sehingga hasil yang didapat $100 \%$ termasuk dalam kategori A. Jika dilihat dari penilaian hasil kerja pada proses membubut dan mengebor diameter apabila masuk kedalam acuan industri maka masuk kedalam kategori E atau masuk kedalam barang reject, pada proses membubut $\varnothing 8.5$ dan membubut $\varnothing 14$, sehingga pada proses membubut diameter sebagian siswa belum kompeten dalam bidang pemesinan.

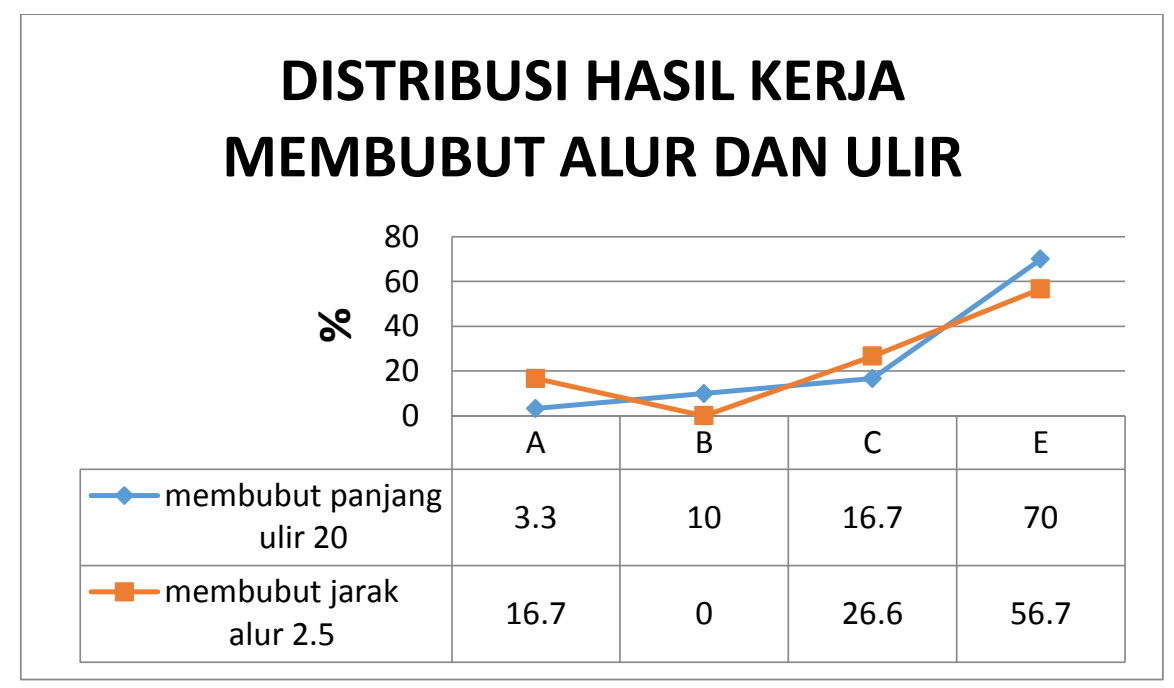

Gambar 3. Grafik penilaian hasil kerja pada proses membubut ulir dan alur 
Apabila dicermati dengan baik, (Gambar 3) terlihat bahwa hasil penilaian dari proses membubut ulir dan alur memiliki titik-titik (koordinat) cenderung berimpitan.Artinya, nilainilai yang diperoleh tidak memiliki perbedaan yang signifikan.Hal ini diperkuat dengan nilai standar deviasi yang tidak terlalu besar, yaitu $<5 \%$.Semakin kecil nilai standar deviasi menunjukkan bahwa data semakin homogen atau cenderung memiliki nilai yang identik, sehingga tingkat penyebaran data dapat dikatakan baik. Sebaliknya, semakin besar nilai standar deviasi maka menandakan bahwa data memiliki kecenderungan yang berbeda satu sama lain atau memiliki variasi yang tinggi, apabila ditinjau dari penilaian menurut industri membubut ulir dan alur masuk kedalam kategori E, karena dilihat persentasi kategori E merupakan presentasi yang paling besar sehingga sebagian siswa masih belum kompeten dalam bidangnya.

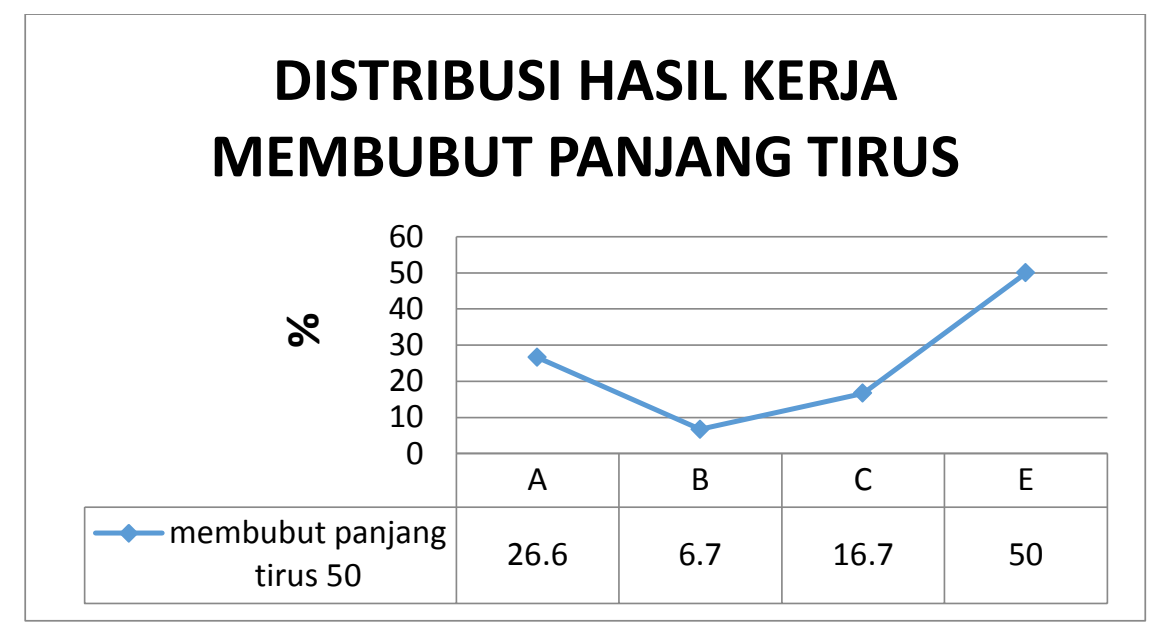

Gambar 4. Grafik penilaian hasil kerja pada proses membubut panjang tirus

Apabila dicermati dengan baik (Gambar 4) terlihat bahwa hasil grafik menunjukan ketidakmerataan kemampuan siswa dalam membubut tirus, disini terlihat yang masuk kedalam kategori A sebesar 26,6\%, kategori B sebesar 6,7\%, kategori C sebesar 16,7\% dan kategori E sebesar 50\%. Sebanyak $50 \%$ masuk kedalam kategori E ini masih banyak siswa ini belum kompeten dibidang pemesinan dalam pelaksanaan uji kompetensi pada proses kerja membubut panjang tirus. 


\section{DISTRIBUSI HASIL KERJA MEMBUBUT PANJANG}

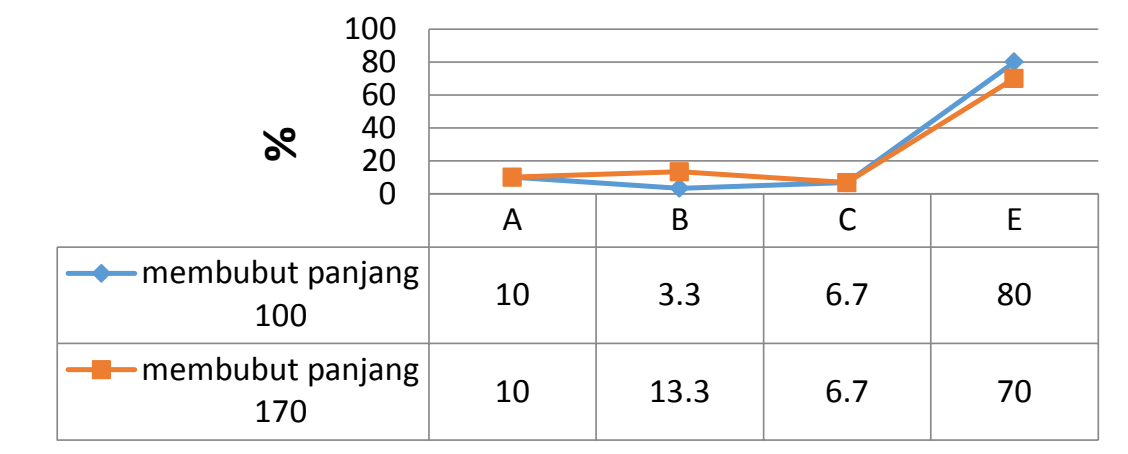

Gambar 5. Grafik penilaian hasil kerja pada proses membubut panjang

Apabila dicermati dengan baik, (Gambar 5) terlihat bahwa hasil penilaian dari proses membubut panjang memiliki titik-titik (koordinat) cenderung berimpitan.Artinya, nilai-nilai yang diperoleh tidak memiliki perbedaan yang signifikan.Hal ini diperkuat dengan nilai standar deviasi yang tidak terlalu besar, yaitu $<5 \%$.Semakin kecil nilai standar deviasi menunjukkan bahwa data semakin homogen atau cenderung memiliki nilai yang identik, sehingga tingkat penyebaran data dapat dikatakan baik. Sebaliknya, semakin besar nilai standar deviasi maka menandakan bahwa data memiliki kecenderungan yang berbeda satu sama lain atau memiliki variasi yang tinggi, apabila ditinjau dari penilaian menurut industri membubut panjang masuk kedalam kategori E, karena dilihat persentasi kategori $\mathrm{E}$ merupakan presentasi yang paling besar sehingga sebagian siswa masih belum kompeten dalam bidangnya.

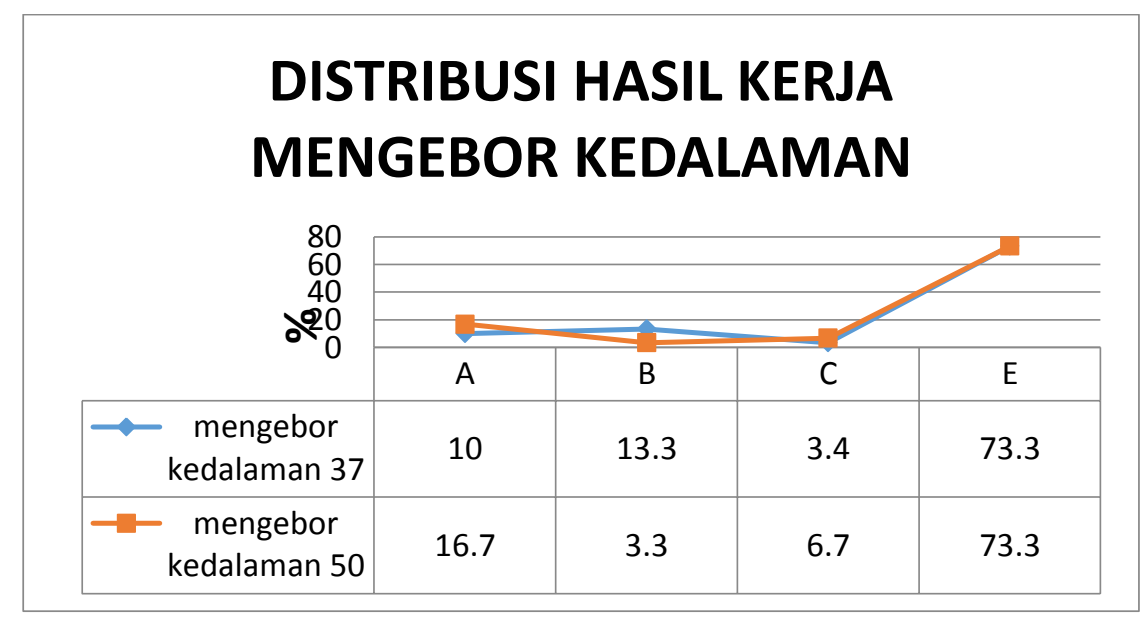

Gambar 6. Grafik penilaian hasil kerja pada proses mengebor kedalaman 
Apabila dicermati dengan baik, (Gambar 6) terlihat bahwa hasil penilaian dari proses mengebor kedalaman memiliki titik-titik (koordinat) cenderung berimpitan.Artinya, nilai-nilai yang diperoleh tidak memiliki perbedaan yang signifikan.Hal ini diperkuat dengan nilai standar deviasi yang tidak terlalu besar, yaitu $<5 \%$.Semakin kecil nilai standar deviasi menunjukkan bahwa data semakin homogen atau cenderung memiliki nilai yang identik, sehingga tingkat penyebaran data dapat dikatakan baik. Sebaliknya, semakin besar nilai standar deviasi maka menandakan bahwa data memiliki kecenderungan yang berbeda satu sama lain atau memiliki variasi yang tinggi, apabila ditinjau dari penilaian menurut industri mengebor kedalaman masuk kedalam kategori E, karena dilihat persentasi kategori E merupakan presentasi yang paling besar sehingga sebagian siswa masih belum kompeten dalam bidangnya.

\section{PEMBAHASAN}

Apabila dilihat dari kenyataan yang ada di industri penilaian pada hasil kerja siswa mengacu pada penilaian pada go dan no go, untuk dunia industri aspek hasil kerja merupakan hal yang paling utama diperhatikan, produk yang menyimpang dari toleransi merupakan barang reject, sehingga produk tidak dapat digunakan atau di buang, hal ini akan menyebabkan kerugian bagi dunia industri apabila produk yang menyimpang dari toleransi sering dilakukan oleh operator, apabila dibandingkan dengan penilaian dari BSNP (Badan Standar Nasional Pendidikan) pada pelaksanaan uji kompetensi praktek kejuruan bidang pemesinan tahun 2013/2014 sangat jauh berbeda dengan dunia industri, pada penilaian hasil kerja BSNP adalah benda yang dikerjakan dengan ukuran toleransi termasuk kategori A, untuk benda yang dikerjakan dengan ukuran menyimpang sebesar 1 toleransi termasuk kategori B, untuk benda yang dikerjakan dengan ukuran menyimpang sebesar 2 toleransi termasuk kategori $\mathrm{C}$, untuk benda yang dikerjakan dengan ukuran menyimpang sebesar 3 toleransi termasuk kategori D, dan untuk benda yang dikerjakan dengan ukuran yang menyimpang sebesar 4 atau lebih dari toleransi termasuk kategori E. Pada penilaian hasil kerja dari BSNP jauh dari dunia industri sementara tujuan dari uji kompetensi praktek kejuruan merupakan sarana untuk mengukur kompetensi siswa calon lulusan SMK apakah siswa itu kompeten atau tidak kompeten dibidangnya yang telah dipelajari selama 3 tahun. 
Sejauh ini lulusan yang kompeten oleh pihak penyelenggara uji kompetensi praktik kejuruan kurang relevan dan dinilai kurang kompeten oleh dunia industri.

Jika mengacu pada format penilaian ukuran (dimensi) dengan batas sebesar $70 \%$, maka dari 11 proses hanya 8 jenis proses yang harus masuk kedalam kategori A, B, C untuk produk hasil kerja yang go. Penilaian hasil kerja di SMK Negeri 6 Bandung dari rata-rata persentasi setiap tipe proses didapat sebesar 21,8\% untuk kategori A, kategori B sebesar 14,2\% dan kategori C sebesar 11,2\%. Bila di jumlah persentasi ini harus lebih besar dari $70 \%$, namun berdasarkan data hanya 47,3\% produk hasil kerja yang go. Sisanya sebanyak $52,7 \%$ Kategori E atau produk hasil kerja yang no go, dari sinilah terlihat bahwa produk hasil kerja siswa sebagian besar masuk kedalam kategori $\mathrm{E}$ atau barang yang reject pada setiap prosesnya, sehingga disini bisa dianggap siswa masih belum kompeten pada pelaksanaan uji kompetensi praktik kejuruan teknik pemesinan. Pelaksanaan ujian kompetensi produktif (UKP) kurang lebih 77,143\% sudah sesuai dengan pedoman pelaksanaan UKP, kesiapan sekolah sudah cukup baik yang dibuktikan dengan tingkat kelulusan 100\%, akan tetapi mutu lulusan harus dikaji lebih lanjut mengingat standar kelulusan merupakan syarat yang diupayakan untuk ditempuh oleh siswa. Sertifikasi masih merupakan formalitas sebagai konsikuensi adanya pelaksanaan ujian kompetensi produktif (Purwanto, 2010).

Implikasi dari pembahasan hasil penelitian yang dilakukan adalah suatu usaha untuk melihat fenomena sesungguhnya yang terjadi. Pada penilaian uji kompetensi pratik kejuruan aspek hasil kerja secara nyata di lapangan. Hal tersebut, diharapkan akan menjadi evaluasi demi perbaikan dan peningkatan kualitas kompetensi dari lulusan SMK. Dalam hal ini, perbaikan indikator penilaian aspek hasil kerja sangat perlu dilakukan dengan pengkajian dan perbaikan ulang (Sudjana, 2005).

\section{KESIMPULAN}

Kesimpulan penelitian in yaitu nilai hasil kerja pada pelaksanaan uji kompetensi praktik kejuruan bidang pemesinan bubut didapatkan nilai hasil kerja rata-rata sebesar 16 . Format penilaian indikator hasil kerja pemesinan distribusikan kedalam kriteria yang dibuat adalah $13.33 \%, 40 \%, 40 \%, 6,67 \%$ untuk masing-masing kategori A,B,C dan E. 


\section{DAFTAR PUSTAKA}

Badan Standar Nasional Pendidikan. (2013). Lembar Penilaian Ujian Praktik Kejuruan Tahun Pelajaran 2013/2014. Jakarta: Depdiknas.

Rochim, T. (2001). Spesifikasi, metrologi, \& control kualitas geometrik. Jilid 1. Bandung: ITB.

Widayanti, A. (2008). Perencanaan Pembelajaran Berbasis Kompetensi. Makalah pada Mata Kuliah Perencanaan Pengajaran UID, Jakarta.

Jihad, A. dan Haris, A. (2013). Evaluasi Pembelajaran. Yogyakarta: Multi Persindo.

Sudjana, N. (2005). Penilaian Hasil Proses Belajar Mengajar. Bandung: PT Remaja Rosda Karya.

Purwanto, N. (2010). Prinsip-prinsip dan Teknik Evaluasi Pengajaran. Bandung: PT Remaja Rosdakarya. 